\title{
DESAIN DAN UJI COBA GAME EDUKASI KIMIA BERBASIS ROLE PLAYING GAME (RPG) PADA MATERI LAJU REAKSI
}

\author{
Ahmad Harianto ${ }^{1}$, Elvi Yenti ${ }^{2}$ \\ ${ }^{1}$ Fakultas Tarbiyah dan Keguruan, Universitas Islam Negeri Sultan Syarif Kasim Riau \\ Email: ahmadharianto077@gmail.com \\ ${ }^{2}$ Fakultas Tarbiyah dan Keguruan, Universitas Islam Negeri Sultan Syarif Kasim Riau \\ Email: elviyenti10@gmail.com
}

\begin{abstract}
This research aimed at developing chemistry education game of role playing game (RPG) based on the reaction rate material and to know product quality based on assessment of media, material experts and chemistry teacher subject. This research used the research and development method which refers to development models from Borg and Gall. The conclusion of this research was the chemistry education game of role playing game $(R P G)$ on reaction rate based that was developed fulfills the criteria both of as a media learning chemistry independence. The media expert gave good scores (75.00\%), the material expert gave good scores (80.00\%), the teachers gave very good scores (92.00\%). In the first filed try out, the students gave very good responses (92.10\%). The qualitative assessment was suggestions from validators, teachers and students who said that chemistry education game of role playing game (RPG) based on the material of the factors influencing reaction rate have been said good.
\end{abstract}

Keywords : Developing Chemistry Education Game, RPG Maker Vx Ace, Reaction Rate.

\section{PENDAHULUAN}

Perkembangan ilmu pengetahuan teknologi informasi dan komunikasi, telah memberikan dampak yang begitu besar bagi dunia pendidikan terutama dalam teknologi pembelajaran. Teknologi pembelajaran di manfaatkan, sebagai pengembangan aneka sumber belajar yang menawarkan berbagai inovasi dan kemudahan untuk membuat peroses pembelajaran menjadi lebih menarik dan menyenangkan. Salah satunya adalah dengan mengembangkan media pembelajaran yang berbasis teknologi menggunakan komputer.

Beragam fasilitas teknologi informasi dan komunikasi yang berkembang pada saat ini, telah menjadi kebutuhan pokok setiap individu, baik itu orang dewasa maupun seorang siswa. Salah satu fasilitas yang ditawarkan oleh perkembangan teknologi adalah hiburan berupa fitur game. Dimana banyak siswa yang menghabiskan waktunya untuk bermain game. Game memiliki pesona dan daya tarik tersendiri, sehingga membuat para pemainnya kecanduan dan terlena.
Fenomena ini mengakibatkan siswa sering melupakan waktu belajar karena waktu yang seharusnya digunakan untuk belajar dihabisakan dengan bermain game (Sari, dkk., 2014). Tentunya fenomena ini akan menambah permasalahan dalam pembelajaran di sekolah, terutama dalam pembelajaran kimia.

Berdasarkan hasil wawancara dengan guru kimia di SMAN Dharma Pendidikan, bahawasannya siswa kurang memiliki motivasi belajar. Hal ini disebabkan mata pelajaran kimia di rasa sulit oleh siswa. Selain itu, banyak siswa yang merasa malas untuk belajar ataupun mengulang pelajaran dirumah. Ilmu kimia memiliki karakteristik yang berbeda dengan ilmu lainnya yakni sebagian besar ilmu kimia bersifat tak kesat mata seperti atom, ion, molekul. Sebagian besar bahan kimia yang ada di alam merupakan campuran zat-zat yang kompleks dan rumit. Kemudian ilmu kimia juga melibatkan hitungan matematis yang terkait dengan hukum dan fakta-fakta kimia, aturanaturan kimia, peristilahan kimia dan bukan 
hanya sekedar perhitungan dalam memecahkan soal-soal (Kurniawati, 2018: 2-3). Hal inilah yang membuat siswa mengalami kesulitan dalam memahami istilah, konsep yang abstrak dan perhitungan matematika (Kurniawati, 2017: 152).

Berdasarkan uraian yang telah dijelaskan sebelumnya, maka perlu adanya inovasi untuk mengatasi permasalahan tersebut yakni dengan mengembangkan game edukasi kimia. Game edukasi yang dikembangkan harus memenuhi kriteria pembelajaran, dalam Peraturan Menteri Pendidikan dan Kebudayaan Nomor 22 Tahun 2016 yang menyatakan bahwa proses pembelajaran diatur secara interaktif, menginspirasi, menyenangkan, menantang, memotivasi siswa untuk berpartisipasi aktif, dan menyediakan ruang yang cukup untuk inisiatif, kreativitas, dan kemandirian sesuai dengan bakat, minat, dan perkembangan fisik dan psikologi siswa (Kemendikbud, 2016).

Game edukasi adalah game yang didesain untuk belajar, gabungan dari konten edukasi, prinsip pembelajaran, dan permainan komputer (Nouval., dkk., 2015: 1-13). Tujuan dari game berjenis edukasi ini yaitu untuk memancing minat belajar siswa terhadap materi pelajaran sambil bermain, sehingga dengan perasaan senang diharapkan siswa dapat lebih mudah memahami materi pelajaran yang disajikan. Sehingga penggunaan media game diperlukan untuk meningkatkan pemahaman siswa. Selain itu media pembelajaran game edukasi ini sebagai sumber belajar mandiri yang dapat digunakan siswa dengan atau tanpa guru mata pelajaran yang bersangkutan (Sari, dkk., 2014 : 98).

Relevan dengan penelitian yang dilakukan oleh Kurnia Wening Sari, Sulistyo Saputro, dan Budi Hastuti menyatakan bahawa game edukasi kimia berbasis Role Playing Game (RPG) pada materi struktur atom untuk siswa kelas X SMA dapat dikembangkan melalui metode penelitian dan pengembangan. Media pembelajaran game edukasi yang dikembangkan memenuhi kriteria baik sebagai pembelajaran kimia mandiri. Berdasarkan uraian latar belakang di atas, maka perlu dilakukan penelitian untuk menghasilkan media pembelajaran yang sesuai kebutuhan siswa. Peneliti tertatik untuk melakukan penelitian dengan judul Desain dan Uji Coba Game Edukasi Kimia Berbasis Role Playing Game (RPG) pada Materi Laju Reaksi. Peneliti berharap dengan adanya media pembelajaran berupa game edukasi ini dapat digunakan sebagai sumber belajar mandiri yang menyenangkan.

\section{METODE PENELITIAN}

Penelitian ini menggunakan jenis penelitian dan pengembangan atau Research and Development (R\&D). Penelitian dan pengembangan adalah metode penelitian yang digunakan untuk menghasilkan produk tertentu, dan menguji keefektifan produk tersebut (Emzir, 2015: 263). Produk-produk yang dihasilkan oleh penelitian dan pengembangan mencakup: materi pelatihan guru, materi ajar, seperangkat tujuan perilaku, materi media, dan sistem-sistem manajemen.

Produk yang dimaksud tidak selalu berbentuk benda atau perangkat keras (hardware) seperti buku, modul, alat bantu pembelajaran di kelas atau di laboratorium, tetapi bisa juga berupa perangkat lunak (software) seperti program komputer untuk pengolahan data, pembelajaran di kelas, perpustakaan, ataupun model-model pendidikan, pembelajaran, pelatihan, bimbingan, evaluasi dan lain-lain (Sukmadinata, 2005: 164-165). Dalam penelitian ini, peneliti membuat sebuah desain Game Edukasi Kimia berbasis Role Playing Game (RPG) pada materi laju reaksi.

\section{Prosedur Pengembangan}

Penelitian pengembangan ini menggunakan desain penelitian dan pengembangan (Research and Development) dengan model prosedural. Model prosedural adalah model deskripsi yang menggambarkan alur atau langkah-langkah prosedur yang harus diikuti untuk menghasilkan suatu produk tertentu. Model prosedural berupa urutan langkah-langkah yang diikuti secara bertahap dari langkh awal hingga langkah akhir. Model prosedural biasa dijumpai dalam model rancangan sistem pembelajaran.

Brog dan Gall mengemukakan prosedur dalam penelitian dan pengembangan bersifat siklus yang terdiri dari 10 langkah 
penelitian (Emzir, 2015: 270). Pada penelitian pengembangan ini mengacu pada prosedur penelitian pengembangan Sugiyono yang disesuaikan dengan kebutuhan peneliti. Langkah-langkah yang digunakan dalam penelitian ini meliputi: 1) Penelitian dan pengumpulan data, 2) Perencanaan, 3) Pengembangan produk awal, 4) Uji coba lapangan awal, 5) Revisi produk, 6) Uji coba lapangan, 7) Revisi produk operasional, 8) Uji pelaksanaan lapangan oprasional, 9) Penyempurnaan produk akhir, dan 10) produksi massal (Emzir, 2015: 270). Namun, pada penelitian ini hanya dilakukan hingga tahap kelima yaitu revisi produk. Berikut ini tahap pada model Brog and Gell.

\section{a. Pengumpulan Data}

Pada tahap ini, dilakukan analisa untuk mengetahui kebutuhan pembelajaran terhadap media pembelajaran yang akan di kembangkan.

1) Studi lapangan dilakukan untuk mengetahui analisis kebutuan media pembelajaran di SMAN Dharma Pendidikan Kempas, Indragiri Hilir.

2) Studi pustaka mengenai teori yang berhubungan dengan desain game edukasi dan materi kimia laju reaksi.

\section{b. Perencanaan}

Tahap perencanaan dimulai dengan membuat alur cerita (storyline), tata cara permainan (gameplay), karakter, peta (maps), event dan suara (sound). Kemudian dilanjutkan dengan membuat flowchart (diagram alir) yang berfungsi sebagai kerangka pembuatan game edukasi. Selanjutnya pembuatan storyboard yakni gambaran media game edukasi secara keseluruhan yang akan dimuat dalam aplikasi. Storyboard berfungsi sebagai panduan dalam proses pembuatan media game edukasi berbasis role playing game.

\section{c. Desain Produk Awal}

Tahap berikutnya adalah mendesain produk awal berdasarkan perencanaan atau panduan storyboard yang telah dibuat. Rancangan yang telah didesain dikelola atau dikonstruksi menggunakan program RPG Maker VX Ace.

\section{d. Validasi dan Uji Coba Produk}

Validasi dilakukan dengan meminta pendapat kepada beberapa ahli media untuk menilai produk game edukasi kimia yang dibuat. Setelah divalidasi produk di uji coba untuk mengetahui apakah produk yang dibuat telah memenuhi kriteria yang telah ditentukan. Hasil uji coba ini berupa tanggapan guru dan peserta didik terhadap media pembelajaran kimia game edukasi kimia berbasis role playing game pada materi kimia laju reaksi.

\section{e. Tahap Revisi}

Revisi dilakukan setelah produk divalidasi oleh ahli materi, ahli media, uji praktikalitas oleh guru dan respon siswa. Revisi bertujuan untuk memperbaiki konten-konten yang kurang sesuai berdasarkan hasil uji coba awal.

\section{Subjek Penelitian}

Subjek penelitian ini meliputi: 1) Ahli Media, 2) Ahli Materi, 3) Guru kimia SMAN Dharma Pendidikan Kempas, Indragiri Hilir dan 4) 10 Peserta didik kelas XI MIPA SMAN Dharma Pendidikan Kempas, Indragiri Hilir.

\section{Teknik Pengumpulan Data}

Instrumen penelitian yang digunakan oleh peneliti yaitu wawancara dan angket (kuesioner). Wawancara digunakan sebagai teknik pengumpulan data apabila peneliti ingin melakukan studi pendahuluan untuk menemukan permasalahan yang harus diteliti, tetapi juga apabila peneliti ingin mengetahui hal-hal dari responden lebih mendalam (Sugiono, 2013: 114). Sedangkan angket disusun berdasarkan kriteria-kriteria yang terdapat dalam evaluasi sumber belajar dan evaluasi game edukasi kimia. Angket ini dibuat untuk ahli materi, ahli media, guru kimia, dan siswa dengan angket yang berbeda sesuai dengan fungsi dan kepentingan masing-masing. Lembar validasi yang digunakan untuk validasi ahli materi, dan ahli media menggunakan skala Likert dengan lima alternatif jawaban. Skala Likert adalah skala yang digunakan untuk mengukur sikap, pendapat, persepsi seseorang atau kelompok tentang kejadian (Riduwan, 2014: 38-39).

Tabel 1. Pedoman Skor Penilaian

\begin{tabular}{rc}
\hline Data Kualitatif & Skor \\
\hline SL (Sangat Layak) & 5 \\
\hline
\end{tabular}




\begin{tabular}{lc}
\multicolumn{1}{c}{ Data Kualitatif } & Skor \\
\hline L (Layak) & 4 \\
\hline CL (Cukup Layak) & 3 \\
\hline KL (Kurang Layak) & 2 \\
\hline SK (Sangat Kurang) & 1 \\
\hline
\end{tabular}

Hasil yang diperoleh digunakan sebagai bahan pertimbangan dalam perbaikan game edukasi kimia dan sebagai kesimpulan dalam penelitian. Teknik analisis data yang digunakan untuk mengolah data penelitian dalam penelitian ini yaitu teknik analisa statistik deskriptif melalui uji validitas dan kepraktisan instrumen. Untuk uji validitas instrumen, dilakukan dengan pengujian validitas konstrak dan validitas isi. Validitas konstrak dapat digunakan pendapat dari ahli (judgement expert ). Dalam hal ini, setelah instrumen dikonstruksi tentang aspek-aspek yang akan diukur dengan berdasarkan teori tertentu, maka selanjutnya dikonsultasikan dengan ahli. Para ahli diminta pendapatnya tentang instrumen yang telah disusun. Untuk menentukan persentase kevalidan dan kepraktisan menggunakan rumus;

$$
\text { Persentase kevalidan }=\frac{\text { Skor yang diperoleh }}{\text { Skor maksimal ideal }} \times 100 \%
$$

Hasil persentase kevalidan kemudian ditafsirkan dalam pengertian kualitatif berdasarkan pada tabel berikut (Riduwan, 2007: $15)$.

Tabel 2. Kriteria Hasil Uji Validitas dan Kepraktisan

\begin{tabular}{ccc}
\hline No & Interval & Kriteria \\
\hline 1 & $81 \%-100 \%$ & Sangat Valid \\
2 & $61 \%-80 \%$ & Valid \\
3 & $41 \%-60 \%$ & Cukup Valid \\
4 & $21 \%-40 \%$ & Kurang Valid \\
5 & $0 \%-20 \%$ & Tidak Valid \\
\hline
\end{tabular}

\section{HASIL DAN PEMBAHASAN}

Berikut akan dijabarkan hasil perolehan yang peneliti peroleh dari lapangan berkaitan dengan produk game edukasi kimia pada materi laju reaksi, yaitu sebagai berikut

\section{a. Hasil Pengembangan Produk}

Produk yang dihasilkan dalam penelitian ini yakni berupa game edukasi kimia yang didesain menggunakan software RPG
Maker VX Ace, berisikan materi kimia laju reaksi faktor-faktor yang memengaruhi laju reaksi dan beberapa latihan soal. Produk game edukasi kimia ini diberi nama "MARANTAU", nama ini diambil berdasarkan filosofi minangkabau yang berarti perginya seseorang dari tempat asal untuk menjalani kehidupan atau menimba ilmu.

Game edukasi kimia ini dikembangkan dengan mengacu pada model pengembangan dan Borg \& Gall, yang dibatasi pada beberapa tahap saja. Tahap-tahap tersebut meliputi: a) tahap pengumpulan data; $b$ ) tahap perencaan; $c$ ) tahap pengembangan produk; dan d) tahap validasi dan ujicoba; e) tahap revisi produk. Ardhana juga mengemukakan bahwa prosedur pelaksanaan penelitian pengembangan bukan merupakan langkah-langkah baku yang harus diikuti secara kaku, setiap pengembangan dapat memilih dan menentukan langkah-langkah yang tepat berdasarkan kondisi khusus yang dihadapi dalam proses pengembangan (Amin, 2015: 94). Berdasarkan paparan diatas sehingga peneliti membatasi penelitian hingga tahap revisi awal.

\section{Hasil Validasi}

Data hasil validasi yang diperoleh dari validator (ahli) terdiri dari data hasil validasi ahli media dan data hasil validasi ahli materi. Kedua data tersebut diperoleh dari dosen prodi pendidikan kimia UIN Suska Riau sebagai validator (ahli). Selain data hasil validasi, juga terdapat data hasil penilaian oleh guru kimia dan respon peserta didik terhadap game edukasi kimia yang dikembangkan.

Data yang diperoleh dari penilaian validator, guru kimia dan respon peserta didik berbentuk data kualitatif. Berdasarkan teknik analisis data, maka data tersebut dirubah kedalam bentuk data kuantitatif. Data kemudian di tampilkan dalam bentuk tabel dan di analisis setiap aspek penilaiannya. Data hasil penilaian produk game edukasi kimia yang dikembangkan adalah sebagai berikut.

\section{a) Data hasil penilaian Produk dari ahli materi dan ahli media}

Berdasarkan penilaian dari validator (ahli) terhadap produk game edukasi kimia yang dikembangkan, didapatkan data kualitas dan masukan-masukan untuk memperbaiki produk. 
Aspek yang dinilai oleh ahli media adalah aspek navigasi, teks, kebahasaan, tampilan audio dan visual, karakteristik, sedangkan aspek yang dinilai oleh ahli materi adalah aspek materi dan soal latihan. Data penilaian hasil validasi ahli media dapat dilihat pada Gambar 1, sedangkan data penilaian hasil validasi ahli materi dapat dilihat pada Gambar 2.

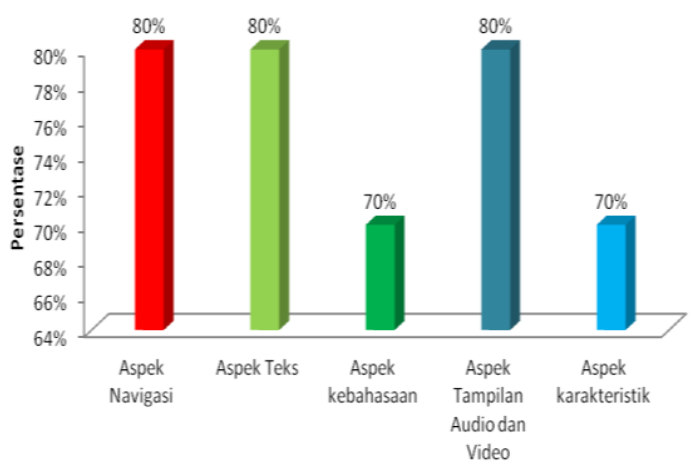

Gambar 1. Grafik Hasil Penilan Media Pembelajaran

Berdasarkan Gambar 1, terlihat bahwa media game edukasi kimia yang dikembangkan dinyatakan "valid" dengan persentase keidealan $75 \%$.

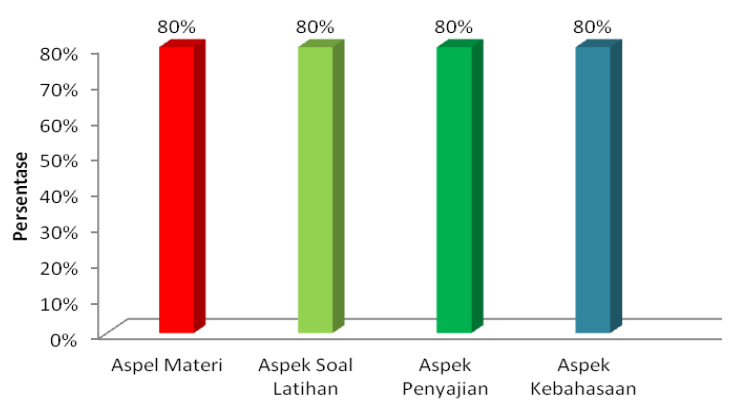

Gambar 2. Grafik Hasil Penilaian Media Pembelajaran oleh Ahli Materi

Berdasarkan Gambar 2, terlihat bahwa semua aspek memiliki kriteria "valid" dengan persentase kevalidan sebesar $80 \%$.

b) Data hasil penilaian produk oleh guru kimia

Penilaian kualitas produk dilakukan oleh dua guru kimia SMAN Dharma Pendidikan Kempas Kab. Indragiri Hilir, yang meliputi aspek navigasi, teks, kebahasaan, tampilan audio visual, karakteristik, buku panduan guru dan peserta didik, materi dan soal latihan. Rekapitulasi data hasil penilaian guru disajikan pada Gambar 3.

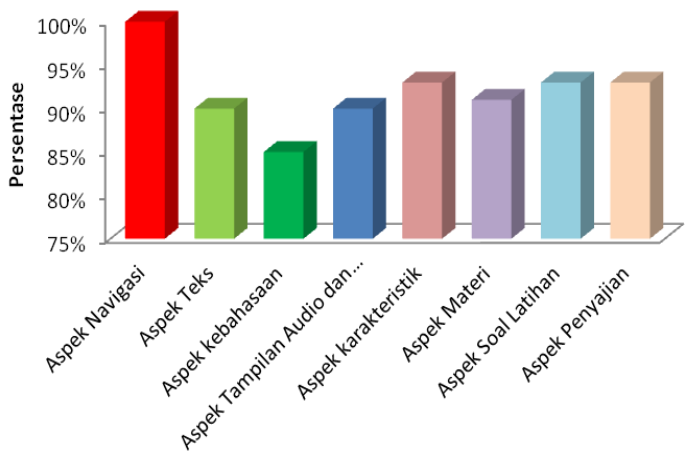

Gambar 3. Grafik Hasil Penilaian Media Pembelajaran oleh Guru Kimia

Berdasarkan hasil penilaian guru pada Gambar 3, terlihat bahwa semua aspek memiliki kriteria sangat praktis. Skor total penilaian dari seluruh aspek produk adalah 258 , dengan pesentase keidealan seluruh aspek $92 \%$.

c) Data respon peserta didik terhadap produk yang dikembangkan

Respon peserta didik terhadap game edukasi kimia dilakukan dengan memberikan angket kepada sepuluh orang peserta didik kelas XI SMAN Dharma Pendidikan Kempas Kab. Indragiri Hilir. Meliputi aspek navigasi, teks, kebahasaan, tampilan audio visual, karakteristik, fungsi media pembelajaran, respon terhadap kimia. Data hasil respon peserta didik dapat dilihat pada Gambar 4.

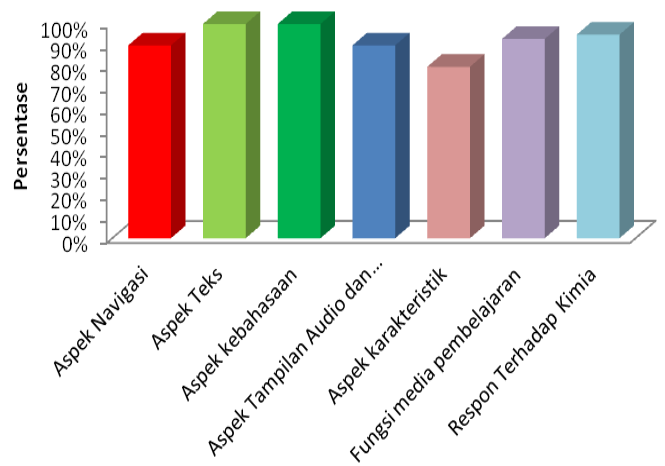

Gambar 4. Grafik Hasil Respon Peserta didik terhadap Media Pembelajaran

Berdasarkan Gambar 4, aspek teks dan kebahasaan memiliki persentase tertinggi yakni $100 \%$, sedangkan aspek nilai terendah adalah 
aspek karakteristik yakni $80 \%$. Data hasil respon peserta didik bukan merupakan aspek penilaian untuk menentukan kualitas produk, melainkan untuk melihat respon peserta didik terhadap game edukasi kimia yang dikembangkan. Kesimpulan dari data tersebut, bahwa produk yang dikembangkan oleh peneliti direspon oleh peserta didik dengan sangat baik (SB).

Kelebihan dan kelemahan game edukasi kimia berbasis role playing game (RPG) yaitu:

\section{1) Kelebihan Produk}

a) Produk game hasil pengembangan berbentuk softwere, sehingga mudah untuk di produksi skla besar dan biyaya produksi tidak mahal.

b) Pada umumnya media yang berbentuk game disukai peseta didik.

c) Produk game edukasi dapat digunakan sebagai sumber belajar mandiri.

d) Produk game dapat digunakan kapanpun dan dimanapun untuk belajar, sesuai dengan keinginan peserta didik.

\section{2) Kelemahan Produk}

a) Hanya memuat materi faktor-faktor yang memengaruhi laju reaksi, sehingga perlu adanya referensi sumber belajar yang lain agar mendapatkan informasi yang relevan.

b) Produk game hanya dapat dijalankan pada sistem operasi windos.

c) Keberhasilan pembelajar tergantung pada kemandirian peserta didik dan motivasi belajar.

\section{SIMPULAN}

Berdasakan hasil penelitian desain dan uji coba game edukasi kimia berbasis Role Playing Game (RPG), maka dapat diambil kesimpulan bahwa penelitian ini telah menghasilkan media pembelajaran berupa game edukasi kimia berbasis role playing game pada materi laju reaksi, dengan mendisain game edukasi kimia menggunakan software RPG Maker Vx Ace.

Adapun penilaian validasi dan paktikalitas game edukasi kimia berbasis Role Playing Game (RPG) sebagai berikut :

a. Validator ahli materi dengan persentase total sebesar $80 \%$ dengan kriteria valid. b. Validator ahli media dengan persentase total sebesar $75 \%$ dengan kriteria valid.

c. Tanggapan penilaian guru melalui uji praktikalitas memperoleh persentase sebesar 92\% dengan kategori sangat praktis.

d. Respon peserta didik kelas XI MIPA 2 SMAN Dharma Pendidikan Kempas terhadap keseluruhan desain game edukasi kimia berbasis role playing game (RPG) yang dikembangkan dengan persentase sebesar $92,1 \%$ menyatakan sangat bagus. Hal ini menunjukkan bahwa media game edukasi kimia berbasis role playing game (RPG) dapat diujicobakan untuk implementasi.

\section{REFERENSI}

Ahmad Kholiqul Amin. (2015). Pengembangan Media Pembelajaran Berbentuk Aplikasi Android Berbasis Weblog untuk Meningkatkan Hasil Belajar Mahasiswa Pendidikan Matematika IKIP PGRI Deponegoro, Megistra, No. 94.

Emzir. (2015). Metodologi Penelitian Pendidikan Kuantitatif dan Kualitatif. Jakarta: PT Rajagrafindo Persada.

Kemendikbud. (2016). Peraturan Menteri Pendidikan dan Kebudayaan Republik Indonesia Nomor 23 Tahun 2016 Tentang Standar Penilaian Pendidikan. Jakarta: Kemendikbud-RI.

Kurniawati, Y. (2017). Analisis Kesulitan Penguasaan Konsep Teoritis dan Pratikum Kimia Mahasiswa Calon Guru Kimia. Jurnal Konfigurasi, 146153.

Kurniawati, Y. (2018). Teknik Penyusunan Isntrumen Penelitian Pendidikan Kimia. Pekanbaru: Kreasi Edukasi.

Nouval Arisco, I. R. (2015). Rancang Bangun Edugame Sport Activity untuk AnakAnak Berbasis Android. 1-13.

Riduwan. (2014). Dasar-Dasar Statistika. Bandung: Alfabeta.

Sari, Kurnia Wening dkk. (2014). Pengembangan Game Edukasi Kimia Berbasis Role Playing Game (RPG) pada Materi Struktur Atom sebagai Media Pembelajaran Mandiri untuk 
Siswa Kelas X SMA di Kabupaten Purworejo. Jurnal Penddikan Kimia, Vol.3 No. 2.

Sugiono, (2013). Metode Penelitian Pendidikan: Pendekatan Kuantitatif,
Kualitatif, dan $R$ \& $D$. Bandung : Alfabeta .

Sukmadinata, Nana Syaodih. (2005). Metode Penelitian Pendidikan. Bandung: Remaja Rosdakarya. 